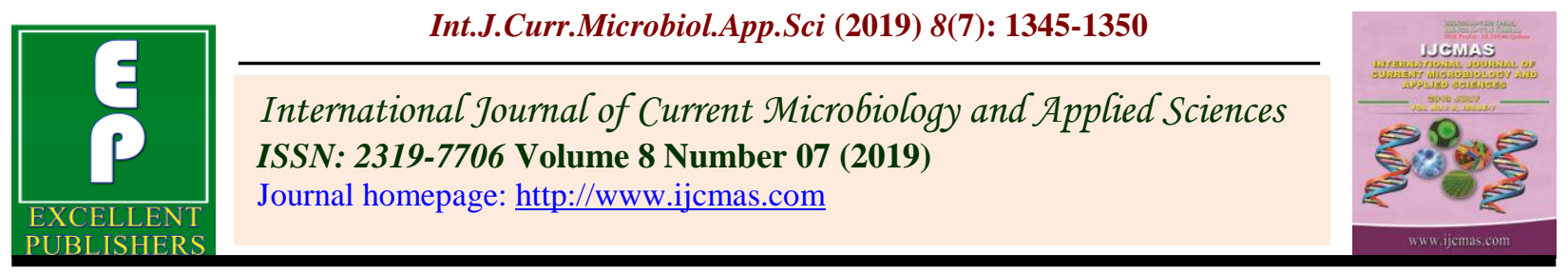

Original Research Article

https://doi.org/10.20546/ijcmas.2019.807.160

\title{
In-vitro Multiple Shoots Production from Cormel Shoot Buds in Gladiolus (Gladiolus hybrida)
}

\author{
Parul Devi, Pushpendra Kumar*, R.S. Sengar, M.K. Yadav, \\ Mukesh Kumar, S.K. Singh and Shilpy Singh
}

Department of Agricultural Biotechnology, Sardar Vallabhbai Patel University of Agriculture and Technology, Meerut, U.P. - 250110, India

*Corresponding author

\section{A B S T R A C T}

Keywords

Gladiolus

hybrida,

in vitro

regeneration,

Growth

regulators,

2,4-D, BAP,

Article Info

Accepted:

12 June 2019

Available Online:

10 July 2019
Gladiolus (Gladiolus hybrida) is an important ornamental plant cultivated world over for its attractive spikes. The commercial cultivation of Gladiolus is based on natural multiplication of corms and cormels. In vitro propagation techniques, is superior to conventional propagation and produces disease free plants in huge quantities. In vitro regeneration of gladiolus cultivars, Sylvia, White Prosperity and Amsterdam was achieved using shoot bud of cormels as an explant. Sylvia variety recorded the best for callus induction and regeneration than other two varieties. The concentration of plant growth regulators affects the regeneration response differently. The highest callus induction rate of $76 \%$ explants was recorded on Murashige and Skoog (MS) medium supplemented with $2 \mathrm{mgl}^{-1}$ 2,4-D (2,4-Dichlorophenoxyacetic acid), after 28 days. MS medium supplemented with BAP at $2.0 \mathrm{mgl}^{-1}$ exhibited higher shoot proliferating efficiency, i.e shoots per explant in Sylvia variety.

\section{Introduction}

Gladiolus (Gladiolus hybrida) is a bulbous ornamental plant. It has a great commercial value in cut flower industry all over the world as well as in India due to its magnificent and colourful spikes. The genus Gladiolus belongs to the family Iridaceae. United States (Florida and California), Holland, Italy, France, Poland, Bulgaria, Brazil, India, Australia and Israel are the major gladiolus producing countries. The major gladiolus producing states in the India are Uttar Pradesh, West Bengal, Odisha, Chhattisgarh, Haryana and Maharashtra. Gladiolus is also grown in states like Uttarakhand, Karnataka, Andhra Pradesh and Sikkim (Kadam et al., 2014). Commercial production of corms and cormels of gladiolus is affected by Fusarium corm rot during storage. Besides, about 25 cormels produce from one mother corm in each season (Sinha and Roy, 2002). These cormels were not able 
to be directly forced to flower, since gladiolus plant was naturally grown as biennial. Thus its commercial cultivation is limited by low rate of multiplication and does not fulfill the local demand of planting material which eventually affects the final cost of corms.

Therefore novel cultivars need to be rapidly mass multiplied by using modern in vitro technologies in order to fulfill the supply gap of huge demand of our local market which is of course not possible through conventional methods. Through modern technologies Mass propagation of corms and cormels such as tissue culture techniques have adopted at commercial level. Advanced countries are using highly sophisticated modern technologies for the commercial production of desired varieties in order to compete in the international markets. In-vitro plant tissue culture makes it possible to produce disease free and true to type planting material of Gladiolus.

In-vitro propagation techniques, prove significance especially for securing rapid multiplication of the novel cultivars. Although there are several research on in vitro propagation of gladiolus varieties using shoot bud, root, leaf and other different parts of plant as explant, and various plant growth regulators such as 2,4-D, IAA, NAA and BAP (Misra et al., 1999; Pathania et al., 2001; Kumari et al., 2005 and Roy et al., 2006). Invitro micropropagation of gladiolus has been reported by using axillary buds (Begum et al., 1995; Boonvanno et al., 2000), shoot tip (Hussain et al., 2001), cormels (Nagaraju et al., 1995) and inflorescence axes (Ziv et al., 2000). Successful protocols for in vitro corm formation (Dantu and Bhojwani, 1995; Sen et al., 1995; Al-Juboory et al., 1995), organogenesis and somatic embryogenesis (Remotti et al., 1995; Kumar et al., 2002) have been achieved also. However, there is a clear scope for further refinement through in vitro culture methodology to acquire a higher number of shoots to complement traditional nursery methods in Gladiolus (Hussain et al., 2001). Present study has been undertaken for standardization of plant growth regulators on MS medium supplemented with PGRs for in vitro differentiation and regenraration of three popular varieties of gladiolus.

\section{Materials and Methods}

\section{Procurement and preparation of explants}

The healthy corms of gladiolus cv. Sylvia, White prosperity and Amsterdam were obtained from Department of Horticulture of Sardar Vallabh Bhai Patel University of Agriculture and Technology (SVPUA\&T), Modipuram, Meerut. Plants were raised in the field laboratory of Department of Agriculture Biotechnology, SVPUA\&T, Meerut for collecting the cormels of gladiolus. These cormels were used for the research work. The outer scale of cormels was removed and shoot buds were cut with the help of surgical blade. Then buds were washed with 3-4 drops of Twin-20 (liquid detergent) along with sodium hypochlorite solution. Then dipped into $1 \%$ bavistin for $10 \mathrm{~min}$ followed $0.1 \% \mathrm{HgCl}_{2}$ solution for 2 minutes. After each treatment, the bud were washed with sterile distilled water, 4 to 5 times. Buds were dried using the blotting paper before inoculated on the media.

\section{Culture media}

\section{Media for callus induction}

MS medium supplemented with various concentrations of plant growth regulators was used for the present study. Callus induction initiated when surface sterilized explants were inoculated on MS medium containing 2,4-D, NAA and IBA. Sucrose 3\% (w/v) was added as carbon source. The $\mathrm{pH}$ was adjusted to 5.8 by $1 \mathrm{~N} \mathrm{NaOH}$ or $1 \mathrm{~N} \mathrm{HCl}$. Agar $0.7 \%$ was 
added as a gelling agent in the medium.

\section{Media for shoot regeneration}

After Callus initiation the explants were placed on MS medium supplemented with various concentrations of BAP, KIN for shoot regeneration. Sucrose 3\% (w/v) was added as carbon source. The $\mathrm{pH}$ was adjusted to 5.8 by $1 \mathrm{~N} \mathrm{NaOH}$ or $1 \mathrm{~N} \mathrm{HCl}$. Agar $0.7 \%$ was added as a gelling agent in the medium. All cultures were maintained at $25 \pm 2{ }^{\circ} \mathrm{C}$ with $16 / 8 \mathrm{~h}$ (light/dark) photoperiod.

\section{Results and Discussion}

In shoot bud culture, plantlets were regenerated via indirect organogenesis, In indirect approach, plantlets were regenerated from callus mass. Cormels shoot bud were cut and transferred into MS medium with varying hormonal concentrations of 2,4-D (0.5 to 4 $\left.\mathrm{mgl}^{-1}\right)$, NAA $\left(0.5\right.$ to $\left.4 \mathrm{mgl}^{-1}\right)$ and IBA (0.5 to 4 $\left.\mathrm{mgl}^{-1}\right)$. Callus induction was successfully observed in the shoot bud explants of Sylvia variety. In Sylvia variety excellent callus formation was observed while in White Prosperity and Amsterdam poor callus formation was observed (Table 1). After four weeks of inoculation, Sylvia variety showed better callus formation as compared to other two varieties. Maximum mass of callus was recorded at the concentrations of auxin $2 \mathrm{mgl}^{-1}$ 2,4-D followed by $2 \mathrm{mgl}^{-1}$ IBA on full strength of MS medium. Kamo (1994) and Grewel et al., (1995) also documented similar findings for diverse explant cultures in gladiolus.

\section{Effect of PGRs on in vitro shoot differentiation from callus of gladiolus}

Shoot regeneration from callus was done by transferring it to MS medium containing various concentrations of Plant Growth Regulators. Shoot induction was observed after 10-20 days of transfer on shoot development media (MS medium supplemented with BAP $1.0 \mathrm{mgl}^{-1}$ and 2.0 $\mathrm{mgl}^{-1}$ ) (Fig 1.B). The result of mean value showed that among all the varieties studied, number of shoots was maximum with the concentration of BAP $\left(1.0 \mathrm{mgl}^{-1}\right.$ and $2.0 \mathrm{mgl}^{-}$ ${ }^{1}$ ) in Sylvia variety. While White Prosperity and Amsterdam variety showed poor number of shoot regeneration (Fig 1. C, D; Table 2). Earlier studies also reported that cytokinin enhances shoot organogenesis (Remotti, 1995; Kumar et al., 2002 ; Aslam et al., 2012).

Table.1 MS basal medium supplemented with different concentration of plant growth regulators for callus induction in gladiolus cultivars, Sylvia, White prosperity and Amsterdam

\begin{tabular}{|c|c|c|c|c|c|}
\hline \multirow[t]{2}{*}{ S. No. } & \multirow[t]{2}{*}{ Treatments } & \multirow[t]{2}{*}{ Media } & \multicolumn{3}{|c|}{ Varietal response to callus formation } \\
\hline & & & Sylvia & White prosperity & Amsterdam \\
\hline 1 & $\mathrm{~T}_{1}$ & $\mathrm{MS}+0.5 \mathrm{mg} / \mathrm{l} 2,4-\mathrm{D}$ & +++ & ++ & - \\
\hline 2 & $\mathrm{~T}_{2}$ & $\mathrm{MS}+1.0 \mathrm{mg} / \mathrm{l} 2,4-\mathrm{D}$ & +++ & + & - \\
\hline 3 & $\mathrm{~T}_{3}$ & $\mathrm{MS}+2.0 \mathrm{mg} / \mathrm{l} 2,4-\mathrm{D}$ & ++++ & ++ & + \\
\hline 4 & $\mathrm{~T}_{4}$ & $\mathrm{MS}+4.0 \mathrm{mg} / \mathrm{l} 2,4-\mathrm{D}$ & ++ & + & ++ \\
\hline 5 & $\mathrm{~T}_{1}$ & $\mathrm{MS}+0.5 \mathrm{mg} / \mathrm{l} \mathrm{NAA}$ & + & - & - \\
\hline 6 & $\mathrm{~T}_{2}$ & $\mathrm{MS}+1.0 \mathrm{mg} / \mathrm{l} \mathrm{NAA}$ & + & - & - \\
\hline 7 & $\mathrm{~T}_{3}$ & $\mathrm{MS}+2.0 \mathrm{mg} / 1 \mathrm{NAA}$ & ++ & - & - \\
\hline 8 & $\mathrm{~T}_{4}$ & $\mathrm{MS}+4.0 \mathrm{mg} / 1 \mathrm{NAA}$ & +++ & +++ & + \\
\hline 9 & $\mathrm{~T}_{1}$ & $\mathrm{MS}+0.5 \mathrm{mg} / \mathrm{IBA}$ & + & - & - \\
\hline 10 & $\mathrm{~T}_{2}$ & $\mathrm{MS}+1.0 \mathrm{mg} / \mathrm{l} \mathrm{IBA}$ & +++ & + & - \\
\hline 11 & $\mathrm{~T}_{3}$ & $\mathrm{MS}+2.0 \mathrm{mg} / \mathrm{l} \mathrm{IBA}$ & ++++ & ++ & + \\
\hline 12 & $\mathrm{~T}_{4}$ & $\mathrm{MS}+4.0 \mathrm{mg} / \mathrm{l} \mathrm{IBA}$ & ++ & + & ++ \\
\hline
\end{tabular}

Abbreviation use in this table: ++++ very good, +++ good, ++ poor, + very poor and - No callus 
Table.2 MS basal medium supplemented with different concentration of cytokinins for regeneration from callus in gladiolus cultivars, Sylvia, White prosperity and Amsterdam

\begin{tabular}{|c|c|c|c|c|c|}
\hline S. No. & Treatments & Media & \multicolumn{3}{|c|}{ Varietal response to micro shoots production (number) } \\
\cline { 4 - 6 } & & & Sylvia & White prosperity & Amsterdam \\
\hline $\mathbf{1}$ & $\mathrm{T}_{1}$ & MS+0.5 mg/l BAP & $3.60 \pm 0.24$ & $2.11 \pm 0.5$ & $5.40 \pm 0.12$ \\
$\mathbf{2}$ & $\mathrm{T}_{2}$ & MS+1.0 mg/l BAP & $9.00 \pm 0.55$ & $1.00 \pm 0.25$ & $4.70 \pm 0.37$ \\
$\mathbf{3}$ & $\mathrm{T}_{3}$ & MS+2.0 mg/l BAP & $9.20 \pm 0.86$ & $2.30 \pm 0.50$ & $3.40 \pm 0.81$ \\
$\mathbf{4}$ & $\mathrm{T}_{4}$ & MS+4.0 mg/l BAP & $4.60 \pm 0.40$ & $5.90 \pm 0.21$ & $3.11 \pm 0.71$ \\
$\mathbf{5}$ & $\mathrm{T}_{1}$ & MS+0.5 mg/l KIN & $5.60 \pm 0.75$ & $10.90 \pm 0.56$ & $6.12 \pm 0.87$ \\
$\mathbf{6}$ & $\mathrm{T}_{2}$ & MS+1.0 mg/l KIN & $4.20 \pm 0.58$ & $9.81 \pm 0.67$ & $4.23 \pm 0.56$ \\
$\mathbf{7}$ & $\mathrm{T}_{3}$ & MS+2.0 mg/l KIN & $5.80 \pm 0.73$ & $7.23 \pm 0.66$ & $5.20 \pm 0.57$ \\
$\mathbf{8}$ & $\mathrm{T}_{4}$ & MS+4.0 mg/l KIN & $6.40 \pm 0.51$ & $6.42 \pm 0.23$ & $6.60 \pm 0.68$ \\
\hline & & Mean \pm Std. error & $6.05 \pm 0.07$ & $5.67 \pm 1.27$ & $4.85 \pm 0.98$ \\
\hline
\end{tabular}

Fig.1 A: Callus induction from cormel shoot buds of gladiolus cv. Sylvia inoculated on full strength MS medium supplemented with 2,4-D $\left(2.0 \mathrm{mgl}^{-1}\right)$, twenty eight days after inoculation. B: Shoot induction in eight week old callus of gladiolus cv. Sylvia inoculated on MS medium supplemented with BAP $\left(1.0 \mathrm{mgl}^{-1}\right.$ and $\left.2.0 \mathrm{mgl}^{-1}\right)$, ten-twenty days after inoculation

C: Shoot induction of gladiolus cv. White Prosperity inoculated on MS medium supplemented with BAP $\left(1.0 \mathrm{mgl}^{-1}\right.$ and $\left.2.0 \mathrm{mgl}^{-1}\right)$, ten-twenty days after inoculation.

D: Shoot induction of gladiolus cv. Amsterdam inoculated on MS medium supplemented with BAP $\left(1.0 \mathrm{mgl}^{-1}\right.$ and $\left.2.0 \mathrm{mgl}^{-1}\right)$, ten-twenty days after inoculation.
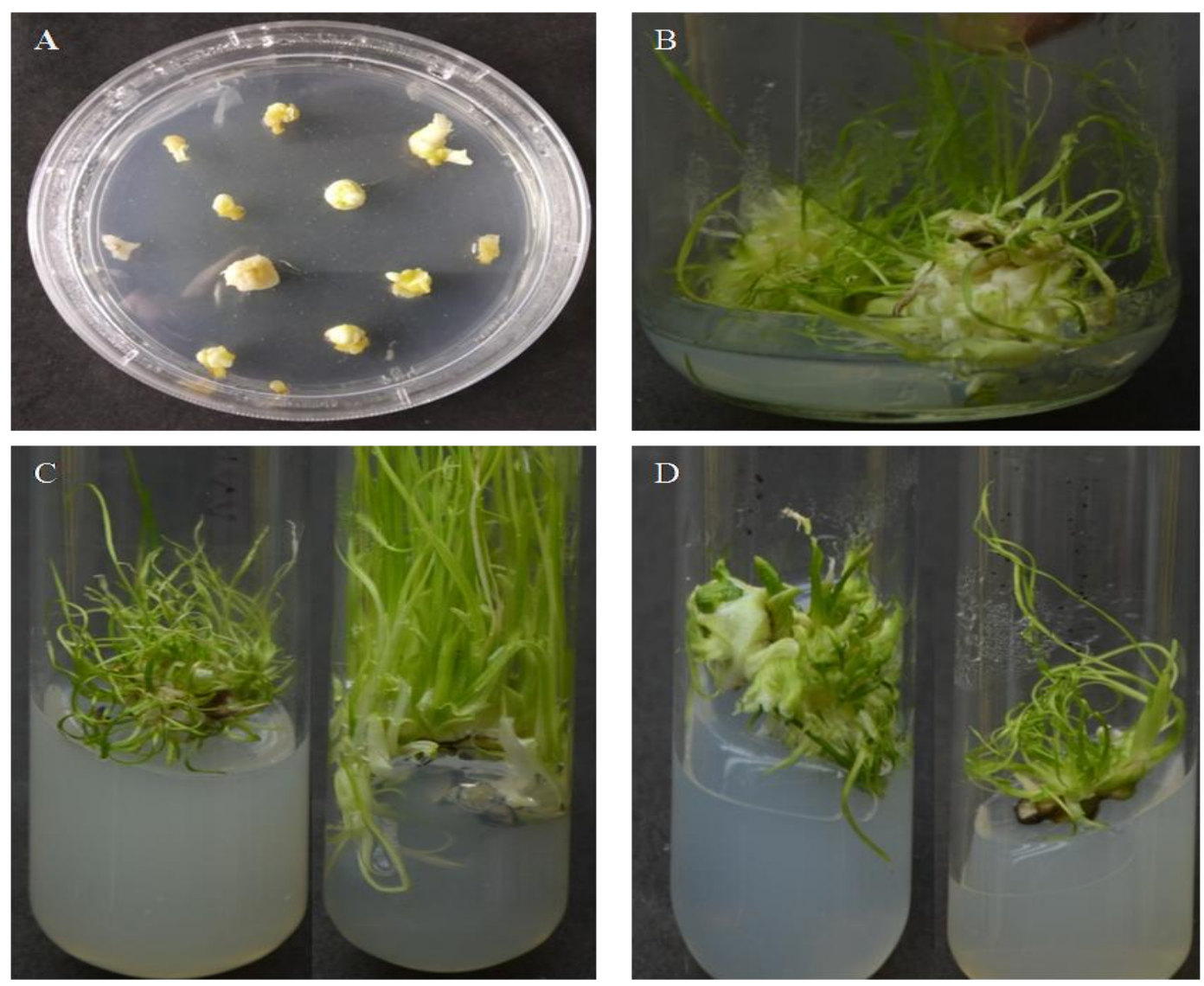
For gladiolus tissue culture experiments, mostly MS basal medium was used by different scientists (Hussey, 1977; Longan and Zettler, 1985; Kamo et al., 1990; Dantu and Bhojwani, 1992). During the present study, basal MS medium was used throughout the experiment as this has been reported more responsive than other medium. Various types and concentrations of plant growth regulators in different combinations were supplemented into basal MS medium. During present investigation, response of three varieties of gladiolus were recorded on MS media supplemented with different auxins and cytokinins concentrations.

\section{References}

Al-Juboory K.H., Shibli R.A., and Skiryn, R. (1995). Organogenesis and cormel production from callus culture of gladiolus cv. Balady. Mu'tah. J. Res. Stud., 12: 143-160.

Aslam, F., Habib, S. and Naz, S. (2012). Effect of different phytohormones on plant regeneration of Amaryllis hippeastrum. Pakistan Journal of Science 64: 54-58.

Begum S. and Haddiuzaman S. (1995). In vitro rapid shoot proliferation and corm development in Glaiolus grandiflorus cv. Red brand. Plant Tissue Cult., 5: 712.

Boonvanno K. and Kanchanapoom K. (2000). In-vitro propagation of gladiolus. Suranaree J. Sci. Technol. 7: 25-29.

Dantu P.K and Bhojwani S.S (1995). In vitro corm formation and field evolution of corm derived plants of gladiolus. Sci. Hort., 61: 115-129.

Grewel, M. S., Arora, J. S. and Gosal, S. S. (1995). Micropropagation of gladiolus through in vitro cormel production. Plant Tissue Culture 5: 27-33.

Hussain I., Muhammad A., Rashid H. and Quraishi A. (2001). In vitro multiplication of gladiolus (Gladiolus crassifolius). Plant Tissue Cult. 11: 121-126.

Hussain, S. C. T., Geetha, C. K., Rajeevan, P. K. and Valsalakumari, P. K. (1994). Plant regeneration from root derived callus in gladiolus. Journal of Ornamental Horticulture 2:46-50.

Hussey G. (1977). In vitro propagation of gladiolus by precocious auxiliary shoot formation. Scientia Horticulturae 6:296.

Kadam J.J, Agale R.C, Rite S.C, Pandav S.M. (2014). Exploration of fungicides and phytoextract against Fusarium oxysporum sp. Gladioli causing corm rot of gladiolus. Discovery Agriculture, 2(9): 61-64.

Kamo K., Chen J. and Lawson R. (1990). The establishment of cell suspension cultures of gladiolus that regenerate plants in vitro. Cell and Developmental Biology 26:425-430.

Kamo, K. (1994). Effect of phytohormones on plant regeneration from callus of gladiolus cultivar's Jenny Lee in vitro Cell and Developmental Biology 30: 26-31.

Kumar A., Palni L.M.S. Sood A., Sharma M., Palni U.T. and Gupta A.K. (2002). Heat shock induced somatic embryogenesis in callus cultures of gladiolus in the presence of high sucrose. Journal of Hort. Sci. and Biotech, 77(1): 73-78

Longan A. E. and Zettler F. (1985). Rapid in vitro propagation of virus indexed gladiolus. Acta Horticulturae 164:16980.

Misra S. and Singh R. (1999). In vitro propagation of gladiolus cv. 'American Beauty’. J. Ornam. Hort., 2: 67-70.

Nagaraju V. and Parthasarthy V.A. (1995). Effect of growth regulators on in vitro shoots of Gladiolus hybridus. Folia Hort, 7: 93-100.

Pathania N.S., Misra R.L. and Raghava S.P.S. (2001). Precocious shoot proliferation 
and microcorm production in gladiolus through tissue culture. Journal of Ornamental Horticulture, 4: 69-73.

Priyakumari I. and Sheela V. L. (2005). Micropropagation of gladiolus cv. 'Peach blossom' through enhanced release of auxiliary buds. Journal of Tropical Agriculture 43:47-50.

Remotti P.C. and Loffler H.J.M. (1995). Callus induction and plant regeneration from gladiolus. Plant Cell, Tissue and Organ Culture, 42: 171-178.

Roy S.K., Gangopadhyay G., Bandyopadhyay T., Modak B.K., Datta S. and Mukherjee K.K. (2006). Enhancement of in vitro micro corm production in gladiolus using alternative matrix. African J. Biotechnol., 5: 1204-1209.

Sen J. and Sen S. (1995). Two step bud culture technique for a high regeneration of gladiolus corm. Sci. Hort., 64: 133-138.

Sinha P. and Roy S.K. (2002).Plant regeneration through in vitro cormel formation from callus culture of Gladiolus primulinus Baker. Plant Tiss. Cult, 12: 139- 145.

Ziv M. and Lilien-Kipnis H. (2000). Bud regeneration from inflorescence explants for rapid propagation of geophytes in vitro. Plant Cell Rep., 19: $845-850$.

\section{How to cite this article:}

Parul Devi, Pushpendra Kumar, R.S. Sengar, M.K. Yadav, Mukesh Kumar, S.K. Singh and Shilpy Singh. 2019. In-vitro Multiple Shoots Production from Cormel Shoot Buds in Gladiolus (Gladiolus hybrida). Int.J.Curr.Microbiol.App.Sci. 8(07): 1345-1350. doi: https://doi.org/10.20546/ijcmas.2019.807.160 